\title{
Role of in vitro and in vivo tests of hypersensitivity in beryllium workers
}

\author{
C. D. PRICE, W. JONES WILliamS, ${ }^{1}$ ANNE PUGH, AND D. H. JOYNSON \\ From The Department of Pathology, Welsh National School of Medicine, Cardiff, and \\ The Public Health Laboratory Service, University Hospital of Wales, Cardiff
}

SUMMARY The value of the beryllium macrophage migration inhibition (Be MIF) and Mantoux. tests in the diagnosis of chronic beryllium disease and in the detection of hypersensitivity in healthy $\vec{\sim}$ beryllium workers is demonstrated.

In the absence of steroid treatment the Be MIF test is positive in chronic beryllium disease ${ }^{\circ}$ patients. Seven of $50(14 \%)$ healthy beryllium workers were Be MIF positive, while all the $\operatorname{control}_{\subset}^{-}$ subjects, normal and sarcoidosis patients, were negative. Healthy beryllium workers tend to be $\stackrel{0}{5}$ more often Mantoux negative than a comparable group of non-exposed workers, and although@ not conclusive this finding correlates with a positive Be MIF test.

Although the detection of hypersensitivity is not diagnostic of disease, the Be MIF test can be $\vec{\theta}$ used as an additional method for monitoring the health of beryllium workers. The full significance. ${ }^{\top}$ of our results should be assessed by a long-term study.

It is now accepted that lymphocyte function tests are of proven value in the detection of delayed (type IV) hypersensitivity (David et al., 1964; David and Schlossman, 1968). In a preliminary study (Jones Williams et al., 1972) using the beryllium induced macrophage migration inhibition test (Be MIF), we found positive results in two of seven patients with chronic beryllium disease. Marx and Burrell (1973), with the same test, found six of seven patients were positive, and Henderson et al. (1972) three out of three. Deodhar et al. (1973) found that the lymphocyte transformation test gave positive results in 25 of 35 patients with chronic beryllium disease. The experimental basis for both these in vitro beryllium hypersensitivity tests is well established (Jones and Amos, 1974; 1975).

As a result of our initial findings we suggested that the Be MIF test would be of value not only in the diagnosis of chronic beryllium disease, but also as a screening test for hypersensitivity in industrial workers, without evidence of disease, who may have been exposed to beryllium. Such in vitro tests of hypersensitivity avoid subject sensitisation inherent

${ }^{1}$ Requests for reprints should be addressed to Dr W. Jones Williams, Department of Pathology, Welsh National School of Medicine, Heath Park, Cardiff.

Received for publication 17 May 1976 in the performance of the skin beryllium patch-test $\frac{0}{\mathrm{D}}$ (Curtis, 1959). It is possible, but remains to be proven $\cong$ by long-term monitoring, that such hypersensitivity $\overrightarrow{\vec{O}}$ may reflect an increased susceptibility to disease. We 3 wish to report and compare the results of Be MIF testing in patients with chronic beryllium disease, industrial workers, potentially exposed to beryllium, without evidence of the disease, and control subjects:including patients with sarcoidosis and normal 3 . healthy persons.

We have also investigated the tuberculin reactivity of the beryllium workers as there is some evidence that beryllium patients and workers tend to be tuberculin negative (Izumi and Jones Williams, 1976).

\section{Material and methods}

\section{SUBJECTS EXAMINED}

Four of the six male patients with chronic beryllium disease were included in our previous report (Jones Williams et al., 1972). The diagnosis of the news? patients was based on a history of exposure to beryllium dust, with clinical, radiological, and histo-0 logical evidence of disease, and the presence of beryllium in the urine.

The 50 male beryllium workers, with one excep tion, were employed in one factory, engaged in the 
machining of pure beryllium. The exception was an administrator in a beryllium ceramic factory. Stringent safety precautions are in force in both factories to avoid beryllium contamination, and careful records are kept of all injuries and possible beryllium exposures. Additional airborne contamination may occur when machines are being serviced when the personal detectors may register beryllium. However, the wearing of face masks, compulsory at such times, should negate any exposure risk. In this population no individual showed clinical evidence of the disease. In most cases the results of chest radiographs were available since the workers undergo periodic radiological examinations. The age, duration of employment, and history of industrial injuries were known in each case.

The control subjects (31) included 11 patients (6 male with clinical and biopsy (Kveim and/or organ) proven sarcoidosis), 7 male industrial workers in miscellaneous occupations, and 13 hospital workers (10 male without beryllium contact, as far as was known).

\section{TECHNIQUE}

White blood cells were separated from $20 \mathrm{ml}$ of heparinised blood by sedimenting for $\mathbf{3}-1$ hour with $2.5 \mathrm{ml}$ Dextran in $0.9 \%$ saline. Cell concentrations were adjusted with Eagle's medium (Wellcome) to give final concentrations of 2.5 and $5.0 \times 10^{6} \mathrm{cells} / \mathrm{ml}$. The cells were then cultured with three concentrations of beryllium sulphate $\left(\mathrm{BeSO}_{4}\right), 10^{-7}, 10^{-8}$, and $10^{-9} \mathrm{M}$. In the control cultures $\mathrm{BeSO}_{4}$ was omitted.

Peritoneal macrophages were obtained from paraffin-oiled guinea-pigs, and migration chambers (Sterilin) were set up, as described by Bloom and Bennett (1971), as follows: Each culture supernatant was used in three wells of a migration plate, each well containing two $20 \lambda$ micropipette tips (Camblab, UK). The areas of migration, measured by plani- metry, were read at both 18 and 24 hours. The migration index was expressed as:

$$
\frac{\text { area of migration with antigen }}{\text { area of migration without antigen }} \text {. }
$$

The effect of $\mathrm{BeSO}_{4}$ concentration was assessed over a large range with respect to:

(a) lymphocyte viability; and

(b) migration inhibition produced in chronic beryllium disease patients.

Lymphocyte viability, when cultured with $\mathrm{BeSO}_{4}$ over a concentration range of $10^{-3}-10^{-10} \mathrm{M}$, was found to be higher than $90 \%$. The MIF index was found to be independent of antigen concentration over the range tested. However, the index was seen to be influenced by lymphocyte concentration when read at 24 hours but not at 18 hours. Consequently, the experimental concentrations used and the time of readings were as above.

It was found, by means of an analysis of variance, that there was no optimum antigen or lymphocyte concentration. Consequently, the 12 readings for each subject were averaged to give a mean MIF index.

The tuberculin reactivity (10 TU) of beryllium workers (48) was compared to that of non-berylliumexposed workers (38) at the same factory. An induration of $5 \mathrm{~mm}$ diameter, or more, at 48 hours was considered positive.

\section{Results}

In order to facilitate comparisons the subjects in each of the three populations were classified on the basis of their mean MIF indices in ranges of 0.06 (Table 1).

\section{CHRONIC BERYLLIUM DISEASE PATIENTS}

Initially, five of the six patients were undergoing

Table 1 Migration inhibition index results for the three populations

\begin{tabular}{|c|c|c|c|c|c|c|c|}
\hline \multirow[t]{2}{*}{ Subjects } & \multirow[t]{2}{*}{ Occupation } & \multirow[t]{2}{*}{ No. } & \multicolumn{5}{|c|}{ Migration inhibition index } \\
\hline & & & $\leqslant 0 \cdot 8$ & $0.81-0.86$ & $0.87-0.92$ & $0.93-0.98$ & $0.99-1 \cdot 15$ \\
\hline \multirow[t]{3}{*}{ Chronic beryllium disease } & Ceramics & 4 & $\mathbf{0}$ & 0 & $4(S)$ & $\mathbf{0}$ & $\mathbf{0}$ \\
\hline & & $1 *$ & $\rightarrow$ & $1(\mathrm{~S})$ & 0 & $\mathbf{0}$ & $\mathbf{0}$ \\
\hline & Metal worker & $1 *$ & $\mathbf{0}$ & $1 \leftarrow$ & 1 (S) & 0 & $\mathbf{0}$ \\
\hline \multirow[t]{5}{*}{ Healthy beryllium metal workers } & Machinist & 34 & 1 & 3 & 8 & 8 & 14 \\
\hline & Melter & 4 & 1 & 0 & $\mathbf{0}$ & 0 & 3 \\
\hline & Scientific & 5 & 0 & 0 & 1 & 3 & 1 \\
\hline & Maintenance & 5 & $\mathbf{0}$ & 1 & 0 & 0 & 4 \\
\hline & Administrator & 2 & 0 & 1 & $\mathbf{0}$ & 1 & $\mathbf{0}$ \\
\hline \multicolumn{8}{|l|}{ Controls } \\
\hline Sarcoidosis & Miscellaneous & 11 & 0 & 0 & 2 & 3 & 6 \\
\hline \multirow[t]{2}{*}{ Healthy } & Industrial & 7 & $\mathbf{0}$ & $\mathbf{0}$ & 1 & 2 & 4 \\
\hline & Hospital & 13 & 0 & 0 & 0 & 1 & 12 \\
\hline
\end{tabular}


steroid treatment and had MIF indices in the $0.87-0.92$ range. The sixth patient, who was not on steroid treatment, had a MIF index of 0.69. To investigate the large difference in MIF indices between those patients on or off steroid treatment, further MIF tests were performed. The MIF index of the one patient not on steroids rose from 0.69 to 0.86 within one month of the start of steroid treatment. When the steroid treatment of one of the five patients was suspended for two weeks his MIF index fell from 0.9 to 0.84 .

BER YLLIUM METAL WORKERS

Seven of the 50 workers had MIF indices below 0.87 , 16 below $0.93,28$ below 0.99 , and 22 above 0.98 .

\section{CONTROLS}

Two of the 11 patients with sarcoidosis had MIF indices below 0.93 , five below 0.99 , and six above 0.98 .

Nineteen of the 20 healthy controls had MIF indices above 0.92 , while one had a MIF index in the $0.87-0.92$ range.

When these results are plotted as a histogram several interesting features emerge (Figure):

1 Control subjects: The overall mean MIF index of the sarcoid patients was 0.99 and that of the healthy persons $1 \cdot 02$.

2 There was little overlap in readings between beryllium diseased patients on steroids and the controls.

3 In $24 \%$ of the beryllium workers the MIF indices fell outside the lower range of the control subjects.

4 Ten per cent of the beryllium workers had MIF indices lower than the chronic beryllium disease patients on steroids.
5 The overall mean MIF index of the beryllium $\underline{\vec{\partial}}$ workers $(0.97)$ differed significantly from that of the healthy control group $(1.04(\mathrm{P}<0.001))$ but $\stackrel{\stackrel{\rho}{+}}{\stackrel{2}{2}}$ not the sarcoid control group (1.00).

6 The overall picture for the beryllium workers was of a normal distribution skewed to the left.

Plotting the $95 \%$ confidence limits, given by Fieller's $\stackrel{\mathbb{Q}}{\Omega}$ theorem (Finney, 1964), in the same manner as Morley (1974) gives a lower MIF index limit of 0.87. In the present study seven beryllium workers have? MIF indices below this value. Details of employment $\vec{\omega}$ and possible additional exposure of these seven were $\stackrel{D}{D}$ determined (Table 2). It was seen that three, with the용 lowest MIF indices had been working at the factory $\dot{\omega}$ in excess of 10 years and had had possible additional airborne exposure; five had incurred some form of $\mathrm{N}$ skin trauma during employment. The subject with $\stackrel{\overrightarrow{0}}{\circ}$ the lowest MIF index had a history of a beryllium- $\mathcal{}$ contaminated skin laceration and also had an equi- $\vec{c}$ vocal chest radiograph. The data concerning these seven workers was then compared with that of the other 43 metal workers with MIF indices above $0.87 ₹$ (Table 3). Other than possibly airborne exposure, the $\overrightarrow{0}$ two groups were indistinguishable in the data $\exists$ concerning their employment.

Five of the six chronic beryllium disease patients, tuberculin tested (10 TU), were all Mantoux negative.

We found (Table 4$)$ that 19 of $48(40 \%)$ beryllium $\frac{2}{\varnothing}$

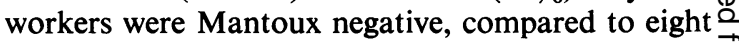
of $38(21 \%)$ non-beryllium-exposed workers. This $\overrightarrow{\overrightarrow{0}}$ difference was not statistically significant $(P=3$ $0 \cdot 11)$.

Three of four beryllium workers with a MIF index of less than 0.87 were Mantoux negative as compared to 12 of 28 with a MIF index greater than 0.87

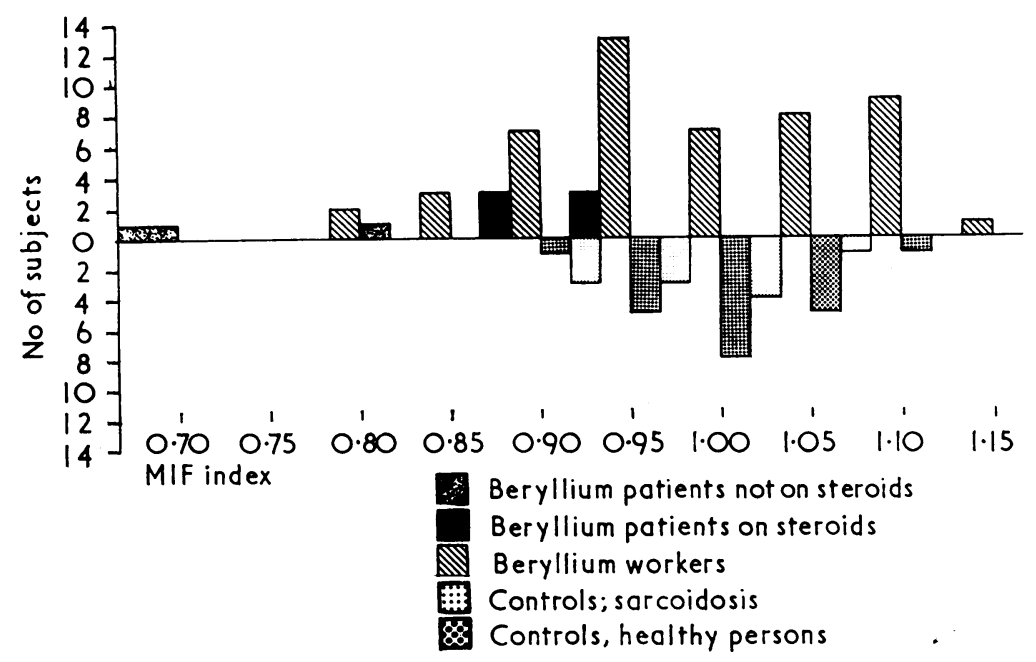

Figure Be MIF index, beryllium patients, workers and control subjects 
Table 2 Bryllium workers (7)-MIF value outside lower $95 \%$ confidence limit

\begin{tabular}{|c|c|c|c|c|c|c|c|c|}
\hline \multirow[t]{2}{*}{ Be MIF } & \multirow{2}{*}{$\begin{array}{l}\text { Age } \\
\text { (yr) }\end{array}$} & \multirow[t]{2}{*}{ Occupation } & \multirow{2}{*}{$\begin{array}{l}\text { Duration of } \\
\text { employment } \\
(y r)\end{array}$} & \multicolumn{4}{|c|}{ Possible additional beryllium exposure } & \multirow[t]{2}{*}{ Radiology } \\
\hline & & & & $\begin{array}{l}\text { No. of } \\
\text { skin } \\
\text { trauma }\end{array}$ & $\begin{array}{l}\text { No. of } \\
\text { foreign } \\
\text { bodies }\end{array}$ & $\begin{array}{l}\text { Beryllium } \\
\text { in wound }\end{array}$ & $\begin{array}{l}\text { Airborne } \\
\text { exposure }\end{array}$ & \\
\hline $\begin{array}{l}0.75 \pm 10.0 \% \\
0.75 \pm 20.0 \% \\
0.83 \pm 14.7 \% \\
0.84 \pm 7.2 \% \\
0.84 \pm 15.4 \% \\
0.85 \pm 5.6 \% \\
0.86 \pm 11.6 \%\end{array}$ & $\begin{array}{l}61 \\
34 \\
48 \\
48 \\
39 \\
50 \\
21\end{array}$ & $\begin{array}{l}\text { Melter } \\
\text { Machinist } \\
\text { Machinist } \\
\text { Maintenance } \\
\text { Machinist } \\
\text { Administrator } \\
\text { Machinist }\end{array}$ & $\begin{array}{r}17 \\
14 \\
16 \\
3 \\
3 \\
7 \\
1\end{array}$ & $\begin{array}{r}7 \\
3 \\
5 \\
1 \\
10 \\
0 \\
0\end{array}$ & $\begin{array}{l}9 \\
4 \\
1 \\
0 \\
6 \\
0 \\
0\end{array}$ & $\begin{array}{l}\text { Once } \\
\text { Never } \\
\text { Never } \\
\text { Never } \\
\text { Never } \\
\text { Never } \\
\text { Never }\end{array}$ & $\begin{array}{l}\text { Yes } \\
\text { Yes } \\
\text { Yes } \\
\text { No } \\
\text { No } \\
\text { No } \\
\text { No }\end{array}$ & $\begin{array}{l}\text { ?Abnormal } \\
\text { Normal } \\
\text { Normal } \\
\text { Normal } \\
\text { Normal } \\
\text { Not done } \\
\text { Normal }\end{array}$ \\
\hline
\end{tabular}

(Table 5), again not statistically significant $(\mathrm{P}=$ 0.253).

Table 3 Comparison between workers with a MIF index above and below 0.87

\begin{tabular}{lcc}
\hline & \multicolumn{3}{l}{$B$ MIF } \\
\cline { 2 - 3 } & $\begin{array}{l}\text { Below 0.87 } \\
(7)\end{array}$ & $\begin{array}{l}\text { Above 0.87 } \\
(43)\end{array}$ \\
\hline Mean age & $43 \cdot 0 \pm 13 \cdot 8$ & $42 \cdot 5 \pm 11 \cdot 6$ \\
Mean no. of years' employment & $8 \cdot 7 \pm 7 \cdot 4$ & $9.9 \pm 5.3$ \\
Mean no. of injuries & $3 \cdot 7 \pm 3 \cdot 8$ & $7 \cdot 4 \pm 7 \cdot 6$ \\
Mean no. of foreign bodies & $2 \cdot 9 \pm 3 \cdot 6$ & $1.9 \pm 3.5$ \\
No. with + ve Be washings & $1(14 \cdot 2 \%)$ & $13(30 \cdot 2 \%)$ \\
No. with possible airborne & $3(42 \cdot 8 \%)$ & $14(32.5 \%)$ \\
exposure & 1 & 1 \\
\hline
\end{tabular}

Table 4 Mantoux tests (10 TU) of factory population

\begin{tabular}{llll}
\hline Beryllium exposure & Total & Positive & Negative \\
\hline Without & 38 & 30 & $8(21 \%)$ \\
Potential & 48 & 29 & $* 19(40 \%)$ \\
\hline
\end{tabular}

*Not significant, $\mathrm{P}=0 \cdot 11$

Table 5 Mantoux tests (10 TU) related to MIF index in potentially exposed workers

\begin{tabular}{lccc}
\hline MIF & Total & Positive & Negative \\
\hline$<0.87$ & 4 & 1 & 3 \\
$>0.87$ & 28 & 16 & $* 12$ \\
\hline
\end{tabular}

*Not significant (Fischer test), $\mathrm{P}=0.253$

\section{Discussion}

The technical complexities of the MIF test, which have recently been critically reviewed (Hughes, 1972; Morley, 1974), may account for some of the variations between and within assays.

\section{CHRONIC BERYLLIUM DISEASE PATIENTS}

Henderson et al. (1972) showed that MIF was produced by the lymphocytes of chronic beryllium disease patients when they were incubated with beryllium oxide. In their study on three patients, they found a mean MIF index of $0 \cdot 58$, which is considerably lower than the findings of the present study. However, it is not clear whether or not the three patients were undergoing steroid treatment. If we compare their figure of 0.58 with the MIF index obtained in the present study of the patient not on steroid treatment, the disparity is considerably reduced. Both studies are agreed, however, that the Be MIF test, whether as a sulphate or oxide, shows positive inhibition in diseased patients. Deodhar et al. (1973), who studied 35 diseased patients using the $\mathrm{BeSO}_{4}$ induced lymphocyte transformation test, found that $71 \%$ of their patients gave a positive reaction with a reasonable correlation between the severity of the clinical disease and the amount of transformation. They also used the Be MIF test but did not publish their findings. It is interesting to note that the patient not on steroids had a MIF index outside the lower $95 \%$ confidence limit, while those on steroids are within the limits. Therefore, it seems that either the MIF and transformation tests are measuring different parameters of lymphocyte function or competence, or alternatively the tests are measuring the same phenomenon but at different sensitivity thresholds.

\section{BERYLLIUM METAL WORKERS}

As far as we are aware, no population at potential risk to beryllium sensitisation has been examined by means of the $\mathrm{Be}$ MIF or any other lymphocyte function test. The results of the present study show that, in all probability, seven workers are sensitised to beryllium. There appear to be no common denominators to these seven, excepting they all work in the same factory processing beryllium. The only parameter possibly associated with 'sensitisation' is airborne exposure. This occurred in $42.8 \%$ of the 'sensitised' subjects but in only $32.5 \%$ of the 'nonsensitised' workers. One of the seven showed an equivocal chest radiograph but the others were 
normal. Furthermore, one of the 'non-sensitised' workers also had an equivocal chest radiograph while having an apparently normal MIF index (1.02).

\section{CONTROLS}

None of the control groups appeared to be sensitised, which is as expected as they had never, to our knowledge, come into contact with beryllium or its alloys. The results of the controls are in themselves support for the reliability of the Be MIF test in that they appear as a normal distribution around approximately 1.00 , and there were no false positives.

Our findings of negative Mantoux reactions in patients with chronic beryllium disease confirm previous reports (Stoekle et al., 1969; Izumi and Jones Williams, 1976).

Izumi and Jones Williams (1976) found that all seven patients from one ceramic factory were tuberculin negative. In addition, $24 \%$ of non-diseased workers at the same factory were tuberculin negative, compared to only $5 \%$ in another similar ceramic factory with no overt beryllium disease, and they suggested that this statistically significant difference may be due to beryllium sensitisation. Our present results, though not statistically significant, show a trend towards tuberculin negativity in potentially exposed beryllium workers as compared to nonberyllium-exposed workers in the same factory.

In conclusion, the Be MIF test is of value in the diagnosis of chronic beryllium disease and may be of value in the long-term monitoring of the health of potentially exposed beryllium workers. The full implications of the latter (for example, are those sensitised workers more liable to develop disease?) must await long-term follow-up studies. There is a suggestion that a negative tuberculin reaction may also be of value in such studies.

The Be MIF test would seem to offer a quick and reliable test in the diagnosis of chronic beryllium disease. As a test of hypersensitivity it obviates the hazard of sensitisation inherent in the performance of the beryllium patch test (Jones and Amos, 1975).

Our results also support the long held view (Tepper et al., 1961) that hypersensitivity plays an important role in the development of beryllium disease.

Dr C. D. Price is in receipt of an MRC Research Grant. Mrs Anne Pugh was supported by Hermal Chemie.

We are grateful to the factory personnel for their kind cooperation and to many clinicians for their assistance and valuable opinions.

\section{References}

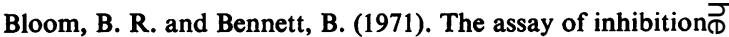
of macrophage migration and the production of migraine $\varrho$ inhibitory factor (MIF) and skin reactive factor (SRF) in the guinea pig. In In Vitro Methods in Cell Mediated. Immunity, edited by B. R. Bloom and P. R. Glades, pp.? 235-248. Academic Press, New York.

Curtis, G. H. (1959). The diagnosis of beryllium disease with $\vec{\omega}$ special reference to the patch test. Arch. industr. Hyg., 19. 150.

David, J. R., Lawrence, H. S., and Thomas, L. (1964). Delayed hypersensitivity in vitro. III. The specificity of hapten protein conjugates in the inhibition of cell migration.J. Immunol., 93, 279-282.

David, J. R., and Schlossman, S. F. (1968). Immunochemical studies on the specificity of cellular hypersensitivity. J. exp. Med., 128, 1451-1459.

Deodhar, S. D., Barna, B., and van Ordstrand, H. S. (1973). A study of the immunologic aspects of chronic berylliosis.? Chest, 63, 309-313.

Finney, D. J. (1964). Statistical Method in Biological Assay, 2nd ed. Griffin, London.

Henderson, W. R., Fukuyama, K., Epstein, W. L., ande Spitler, L. E. (1972). In vitro demonstration of delayed V hypersensitivity in patients with berylliosis. $J$. invest. Derm., 58, 5-8.

Hughes, D. (1972). Macrophage migration inhibition test: a critical examination of the technique using a polythene $\bar{O}$ capillary tubing micromethod. J. Immunol. Meth., 1,0 403-424.

Izumi, T. and Jones Williams, W. (1976). The first sevene cases of chronic beryllium disease in ceramic workers in $\overrightarrow{\bar{\theta}}$ Japan. Proceedings of the VII International Conference on Sarcoidosis. Ann. N.Y. Acad. Sci. 278, 636.

Jones, J. M. and Amos, H. E. (1974). Contact sensitivity in vitro: activation of actively allergized lymphocytes by a. beryllium complex. Int. Arch. Allergy, 46, 161-171.

Jones, J. M. and Amos, H. E. (1975). Contact sensitivity in vitro. II. The effect of beryllium preparations on theo proliferative responses of specifically allergized lympho cytes and normal lymphocytes stimulated with PHA. Int. Arch. Allergy, 48, 22-29.

Jones Williams, W., Grey, J., and Pioli, E. M. (1972). Diagnosis of chronic beryllium disease (Letter). Brit.윽 med.J., 4, 175.

Marx, J. J., Jr. and Burrell, R. (1973). Delayed hyper $\frac{D}{2}$ sensitivity to beryllium compounds. J. Immunol., 111, 590-598.

Morley, J. (1974). Cell migration inhibition: An appraisal.

Acta allerg. (Kbh.), 29, 185-208.
Stoekle, J. D., Hardy, H. L., and Weber, A. L. (1969) N Chronic beryllium disease. Long term follow up of $600 \mathrm{~W}$ cases and selective review of the literature. Amer. J. Med.?

46, 545.
Tepper, L. B., Hardy, H. L., and Chamberlin, R. I. Eds $\frac{0}{\frac{0}{D}}$ (1961). Toxicity of Beryllium Compounds. Elsevier, Amster dam; Van Nostrand, London. 